\title{
A NEW METHOD COMPARING SNOWMELT TIMING WITH ANNUAL AREA BURNED
}

\author{
Donal S. O'Leary III, Trevor D. Bloom, Jacob C. Smith, Christopher R. Zemp, \\ and Michael J. Medler*
}

Western Washington University, 516 High Street, Bellingham, Washington 98225, USA

*Corresponding author: Tel.: +1-360-650-3173; e-mail: Michael.Medler@wwu.edu

ABSTRACT

The interactions between climate and wildland fire are complex. To better understand these interactions, we used ArcMap 10.2.2 to examine the relationships between early spring snowmelt and total annual area burned within a defined region of the Rocky Mountains of the western United States. Our research methods used Monitoring Trends in Burn Severity (MTBS) fire perimeter data and weekly snow extent provided by the Rutgers Global Snow Lab analysis of National Oceanic and Atmospheric Administration (NOAA) daily snow maps. Our results indicated a significant correlation between early spring snowmelt and total annual area burned $(P=0.0497)$, providing further evidence that snowmelt timing may be a driving factor for wildland fires. This project builds on the findings of previous studies and provides a novel method for making general predictions about the upcoming fire season months in advance, using freely available remotely sensed data in real time. Further research should apply our model to a broader geographic area, and incorporate higher resolution snowmelt timing data.

\section{RESUMEN}

Las interacciones entre el clima y los incendios naturales son complejos. Para un mejor entendimiento de estas interacciones, nosotros utilizamos ArcMap10.2.2 para examinar las relaciones entre el derretimiento de la nieve en la primavera temprana y la superficie total anual quemada dentro de una región definida de las Rocallosas en el oeste de los EEUU. Nuestros métodos de investigación utilizaron el Monitoreo de Tendencias en Severidad de Quemas (MTBS por sus siglas en inglés), con datos del perímetro del fuego y la extensión semanal de la nieve, mediante mapas diarios provistos por el Laboratorio Global Rutgers de Análisis de Nieve, dependiente de la Administración Nacional Oceánica y Atmosférica $(N O A A)$. Nuestros resultados indicaron una correlación significativa entre el derretimiento temprano de la nieve y la superficie total anual quemada $(P=0.0497)$, proporcionando evidencias que el tiempo cronológico en el derretimiento de la nieve podría ser un factor favorecedor de los incendios naturales. Este proyecto se apoya en los hallazgos de estudios previos y provee de un método novedoso para hacer predicciones generales sobre las próximas temporadas de fuego con antelación, utilizando datos en tiempo real de sensores remotos disponibles y gratuitos. Más investigaciones deberían realizarse con nuestro modelo para un área geográfica más amplia, e incorporar los tiempos de derretimiento de la nieve con datos de alta resolución. 
Keywords: fire regime, GIS, remote sensing, Rocky Mountains, snowmelt timing, wildland fire

Citation: O'Leary, D.S., III, T.D. Bloom, J.C. Smith, C.R. Zemp, and M.J. Medler. 2016. A new method comparing snowmelt timing with annual area burned. Fire Ecology 12(1): 41-51. doi: 10.4996/fireecology.1201041

\section{INTRODUCTION}

Future changes in wildfire regimes depend on the combined influences of climate, landuse change, human activity, and vegetation (Fauria et al. 2011, Higuera et al. 2015). Although there is no perfect predictor for future wildfires, we present a novel method for correlating snowmelt timing to annual area burned in a particular ecoregion. Our methods build on previous studies utilizing updated remotely sensed datasets and a new snowmelt timing algorithm to compare snowmelt timing and annual area burned from 1984 to 2012 in the Middle Rockies EPA (Environmental Protection Agency) Level III Ecoregion (US EPA 2003; hereafter, Middle Rockies Ecoregion). Our model can easily be extended to any ecoregion in the United States and may be applicable internationally in regions with complete wildfire datasets.

Previous studies have addressed the relationship between early snowmelt timing and wildfire using various methods. Medler et al. (2002) examined the spatial and temporal relationships between snow cover and wildfire from 1986 to 1996 in the 11 western US states. Although their research suggested an inverse relationship between early snowmelt timing and wildfire, no strong statistical correlation was found for the 11 western states as a whole for the period of interest, or when these data were aggregated by state boundaries. This study was limited by the use of political, rather than ecological, boundaries. This is possibly because the use of political boundaries is not ecologically meaningful, and therefore the snow and wildfire interaction that one might expect to see in the montane ecosystems of the Middle Rockies was not well captured. We were interested in identifying relationships between snowmelt timing and wildfire in forested ecoregions, therefore repeating this analysis using sensible ecological boundaries and updated datasets yielded further insight. The Medler et al. (2002) study was also limited by data availability. At the time of their study, fire data were only available for 1986 to 1996. At the time of our study, we had validated fire data for 1984 to 2012, improving our ability to observe trends in spite of decadal climate oscillations. Finally, Medler et al. (2002) used acre-weeks of snow as their snow metric, which does not specifically consider the spring timing of snowmelt. We improved upon this method by identifying a day of year (DOY) for snowmelt for each cell within our study area, providing a more direct comparison between spring snowmelt timing and wildfire occurrence.

Westerling et al. (2006) compiled a comprehensive database of 1166 large wildfires ( $>400 \mathrm{ha}$ ) in the western US between 1970 and 2003 and compared it with hydroclimatic and land-surface data. As a representation for spring snowmelt timing, they used the dates of the center of mass of annual flow for snowmelt-dominated stream flow (CT) gauge records in western North America (Westerling et al. 2006). They found that the annual wildfire frequency was inversely correlated with CT across the study region, indicating that fires corresponded to earlier spring snowmelt. Their study was limited by the use of CT as an indicator of spring timing, as the stream gauge itself is limited to the boundaries of the watershed, and CT is a timing method that is difficult to estimate in real time. For our method, we used remotely sensed data, which allowed us to define our boundaries based on the spa- 
tial resolution of the data and to identify critical snowmelt thresholds in real time at the temporal resolution of the data.

Narasimhan and Stow (2010) used MODIS (Moderate Resolution Imaging Radiometer) snow cover imagery to determine the first completely snow-free days of the year using a fractional snow cover product from 2003 to 2005. Their novel approach was hampered by cloud cover in the Arctic and spring snow events. Our method employed a cloud-free dataset and controls for spring snow events with a temporally averaged melt date. Our analysis spanning 1984 to 2012 also allowed for a more robust interannual comparison of snowmelt timing. Still, the MODIS snow data products give researchers a dramatically improved spatial resolution for environmental investigation. We kept this potential in mind during our statistical analysis when we checked whether the MODIS period of record (2000 to present) showed a different relationship between snowmelt timing and wildfire from the full study period.

Semmens and Ramage (2012) investigated the relationship between snowmelt and wildfire outbreaks using the Advanced Microwave Scanning Radiometer for EOS (AMSR-E), which can detect melt and refreeze cycles at the snow surface. Their method did not consider the timing of snow cover loss, as is calculated here. Additionally, their focus on a single watershed in Alaska may not be relevant to the US Mountain West.

Building on these findings we designed a model to explore the following question: Is there a detectable relationship between snowmelt timing and annual area burned within the Middle Rockies Ecoregion using contemporary remotely sensed datasets?

Observing patterns in wildfire and climate requires extensive and long-term datasets (Higuera et al. 2015). Our research methods used the recent Monitoring Trends in Burn Severity (MTBS) fire perimeter data (Finco et al. 2012) and weekly snow cover extent provided by the Rutgers Global Snow Lab analysis of National Oceanic and Atmospheric Administration (NOAA) daily snow maps (Robinson et al. 2012) for the study period of 1984 to 2012. Our study area was the Middle Rockies Ecoregion, which encompasses the mountainous regions of Wyoming, North Dakota, Montana, and Idaho, USA (Figure 1). These regions are often referred to in other literature as the US Northern Rockies. This region is sensitive to interactions between climate and wildfire and has experienced an increase in large fire occurrences in the last several decades (Littell et al. 2009, Dennison et al. 2014, Higuera et al. 2015).

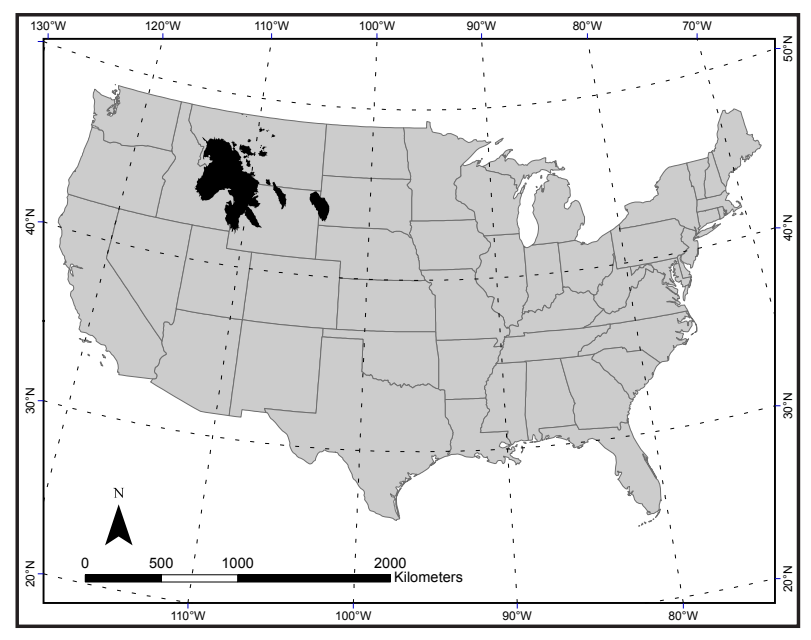

Figure 1. Map displaying the location of the Middle Rockies Ecoregion, within the 48 conterminous United States of America. The Middle Rockies Ecoregion includes the mountain regions of Wyoming, North Dakota, Montana, and Idaho. These regions are often referred to in other literature as the US Northern Rockies. Vector data from EPA and Natural Earth (http://www.naturalearthdata. com).

\section{BACKGROUND}

The paleorecord of the past 6000 years highlights the sensitivity of the Rocky Mountain region to changes in fire regime induced by climatic oscillations (Higuera et al. 2014). In the past four decades, the average annual 
area burned by large fires has increased 10fold in western US forests and is predicted to escalate further (Westerling et al. 2014). A legacy of fire suppression is one of the greatest causes of increased fire activity in recent decades, yet has not affected many portions of the Rocky Mountains (Dennison et al. 2014). The fire regime of the Middle Rocky Mountains is characterized by a long Mean Fire Return Interval (MFRI) followed by infrequent yet high-severity, stand-replacing fires (Baker 2009). Fire suppression did not drastically impact fuel loading in the Middle Rockies Ecoregion because the MFRI of the region's forested ecosystems is greater than the period of suppression spanning the last 100 years (Baker 2009). Together these factors made our study area an ideal region to isolate and explore the complex interaction between climate, in particular snowmelt timing, and fire.

Wildfire is strongly linked to climate variability (Gedalof et al. 2005, Miller et al. 2008, Littell et al. 2009, Fauria et al. 2011, Higuera et al. 2015). Ultimately, fuel moisture content and length of fire season have the largest observed influence on annual area burned (Westerling et al. 2006, Spracklen et al. 2009, Higuera et al. 2015). Many possible climatic factors can lead to dry fuels and increased fire danger. Climatic metrics such as Palmer Drought Severity Index (PDSI), Growing Degree Days, summer and spring mean temperature, and fuel moisture metrics such as Duff Moisture Code can accurately explain upwards of $50 \%$ of annual area burned in historical North American wildfires (Gedalof et al. 2005, Westerling et al. 2006, Miller et al. 2008, Spracklen et al. 2009, Higuera et al. 2015).

Snow cover is a first order control on an ecosystem. The presence or absence of snow has an influence on energy balance, the timing and robustness of vegetation, soil moisture, weathering, and other processes (Moore et al. 2014). As with other climatic factors, early snowmelt can lead to increased annual area burned through the mechanism of precondi- tioning large expanses of fuels to low moisture content and extending fire seasons (Westerling et al. 2006). Remotely sensed snowmelt timing has the potential to advise land managers months before the beginning of fire season. Whereas PDSI, summer temperatures, and fuel moisture levels explain a high percentage of fire activity, they are only available weeks to days before a fire. The snowmelt and wildfire interactions analyzed here will be of particular interest to logistics managers as they distribute resources in preparation of fire season.

The predicted future fire regime of the US Mountain West may not support the persistence of the current community of species (Westerling et al. 2011). As the snow melts earlier, fires become more likely at higher elevations and the MFRI is reduced (Westerling et al. 2006). Predictive models suggest that, as the climate warms, wildfire may become as important as direct effects of climate change in the persistence of high elevation vegetation, including regions in which wildfire is currently rare or absent (Schumacher and Bugmann 2006). Understanding the role of wildfire and snowmelt is critical in order to assess the potential impacts of climate change on North American mountain ecosystems.

\section{METHODS}

For this analysis, our region of study was the Middle Rockies 6.2.10, as defined by EPA Ecoregions Level III (Figure 1). To clarify geographical discrepancies, not all studies define the regions of the Rockies using EPA Ecoregions Level III. For example, the region that Westerling et al. (2006) describe as the "Northern Rockies" overlaps with the Middle Rocky Mountain EPA Ecoregion Level III, including the Greater Yellowstone Ecosystem.

Snow data were acquired from the Rutgers University Global Snow Lab (Robinson et al. 2012). Snow presence in this dataset was mapped weekly on an $89 \times 89$ cell Cartesian grid laid over a polar stereographic projection 
of the Northern Hemisphere beginning in the 1960s (Medler et al. 2002). This NASA (National Aeronautics and Space Administration) MEaSUREs (Making Earth System Data Records for Use in Research Environments) Earth System Data Record (ESDR) contains two separate readings for snow presence: one using the weekly NOAA-NCDC (National Climatic Data Center) Northern Hemisphere Snow Cover Extent Climate Data Record (CDR), and the other from a gap-filled snow extent product derived from the Spectral Sensor Microwave-Imager (SSMI) and the Spectral Sensor Microwave Imager-Sounder (SSMIS). These values were then codified based on snow presence determined by both sensors $($ code $=10)$, CDR only (11), SSMI(S) only (12), and no snow (20). For this research, we assumed that a positive snow code from either or both sensors indicated snow presence, and made our snow or no snow determination accordingly. There were no other values reported for this region.

To determine the timing of snow loss, we considered the differences between the weekly snow presence codes. Snow loss was determined by two consecutive readings of nonsnow values. Occasionally snow would return as evidenced by two consecutive snow covered values, usually as the result of a spring snow event. For these cases, we took the average of the first snowmelt DOY and the final snowmelt DOY. We reported the date of first snow loss as the first instance of the first day of 14 or more consecutive no snow values. We reported date of final snow loss as the last instance of the first date of 14 or more consecutive snow covered values. In most cases, the aforementioned two values were the same. Averaged melt date (AMD) was the average of the date of first snow loss and the date of final snow loss. This snow dataset had 20 data points that fell within the Middle Rockies region. For each year, we calculated the AMD for each point, and then averaged together to determine a mean snowmelt date for the entire region. From those values, we performed calculations for average snowmelt date and standard deviation of snowmelt dates for the period of record, and calculated a $Z$-value for each year on record. A negative $Z$-value indicated a year with an earlier snowmelt than average.

We sourced fire data from the Monitoring Trends in Burn Severity (MTBS) National Burn Area Boundaries data from 1984 to 2012 (MTBS Project 2014). In ESRI ArcGIS10.2.2, we clipped the fire area to the Middle Rocky Mountains, as defined by EPA Ecoregions Level III, resulting in 663 fires from 1984 to 2012 in our study area. From the reported burned area for each fire in the dataset, we calculated the annual area burned in the study area. We calculated the mean and standard deviation of total annual area burned for years 1984 to 2012, and calculated a $Z$-value for each year on record. A positive $Z$-value indicated a year with more fire than average.

We performed statistical analyses in $\mathrm{R}$ version 3.1.2 (R Project for Statistical Computing, Vienna, Austria). The $Z$-value of the regional snowmelt date was compared with the $Z$-value of total annual area burned (Figure 2). We tested our data for temporal autocorrelation using R's ACF function and found no significant autocorrelation for the annual area burned or snowmelt data, leaving us to proceed without corrections. We then subset our dataset to evaluate different periods of record, first omitting the exceptionally large fire year of 1988 (the big Yellowstone fires), then the period of record since the MODIS instruments became operational on the Aqua and Terra satellites (2000 to 2012). We calculated a Spearman's rank correlation between the scaled $Z$-values for annual area burned versus snowmelt timing for each period of interest.

\section{RESULTS}

Visual comparison of total annual area burned versus snowmelt $Z$-values (Figure 2), and scatterplots of the $Z$-values for the differ- 


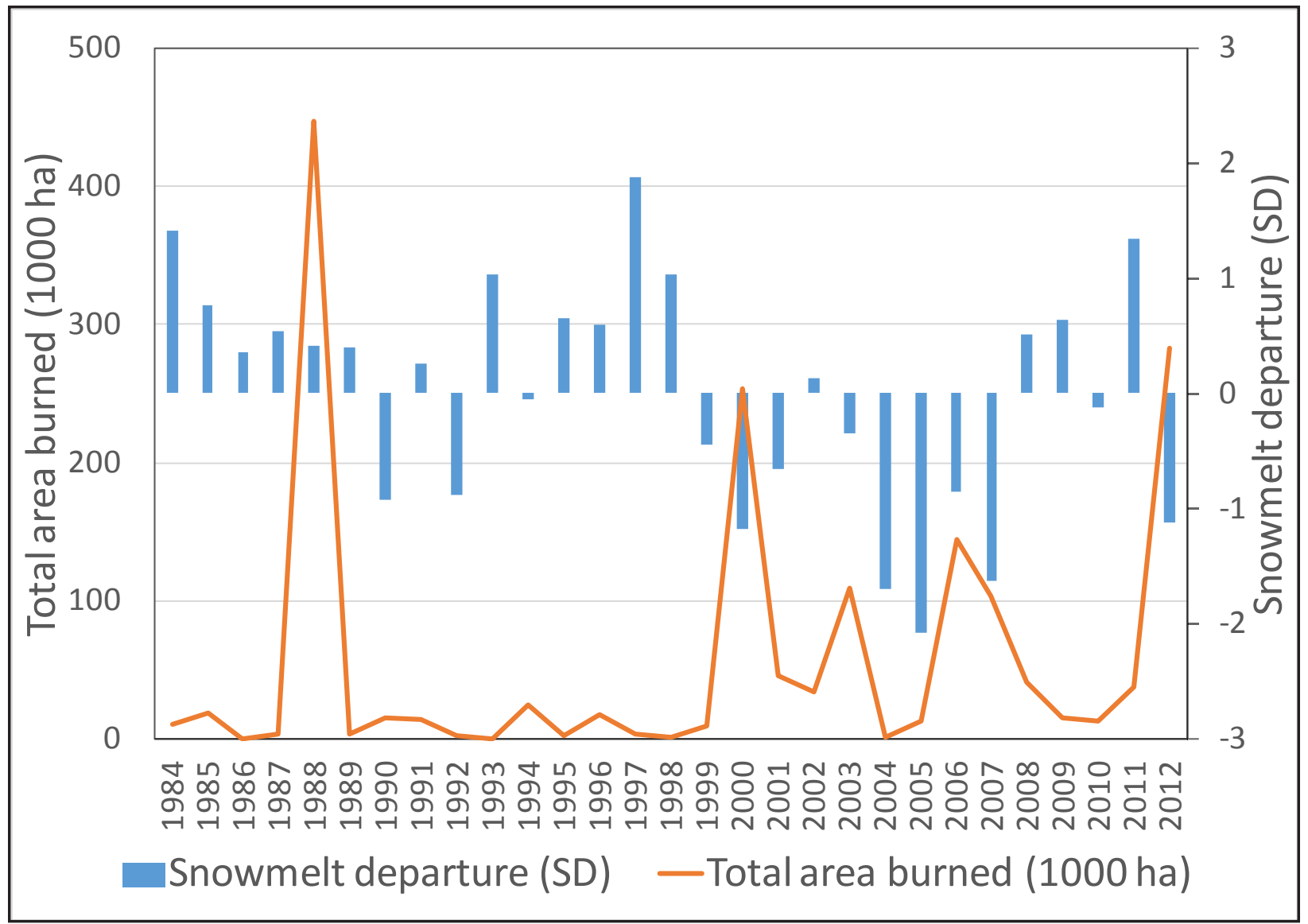

Figure 2. Comparison of snowmelt anomaly and total area burned for the subsequent fire season in the Middle Rockies Ecoregion. The largest fire year (1988) burned when the snow melted slightly later than average, whereas the major fire events of 2000, 2003, 2006, and 2012 all burned on years with an early snowmelt.

ent subsets (Figure 3), suggests that large fire years coincide with early snowmelt. Fire activity generally increased from 1999 to 2012, coinciding with negative snow anomalies, with a relative absence of fire during the later-melting 1984 to 1998 years (with the exception of 1988).

All correlation tests returned negative relationships between snowmelt $Z$-values and annual area burned $Z$-values. The full period of record $\left(\rho_{27}=-0.331, P\right.$-value $\left.=0.0797\right)$ and the subset omitting $1988\left(\rho_{26}=-0.374, P\right.$-value $=0.0497$ ) both showed a strong relationship between snowmelt timing and wildfire occurrence. The subset corresponding to MODIS data availability $\left(\rho_{11}=-0.104, P\right.$-value $=$ 0.737 ) showed little to no relationship between these two variables.

\section{DISCUSSION}

Our results revealed an inverse relationship between snowmelt anomaly and total annual area burned in the Middle Rockies Ecoregion from 1984 to 2012. An earlier spring snowmelt was correlated with above-average annual area burned. These results support the findings of others (Medler et al. 2002, Westerling et al. 2006, Semmens and Ramage 2012). The implications of our findings are especially critical because the average annual area burned in the western US is projected to increase further, and years without fires are predicted to be increasingly rare (Westerling et al. 2011). Additionally, as the climate changes in the US Mountain West, snow is expected to melt progressively earlier in the season (Stewart 2009). 


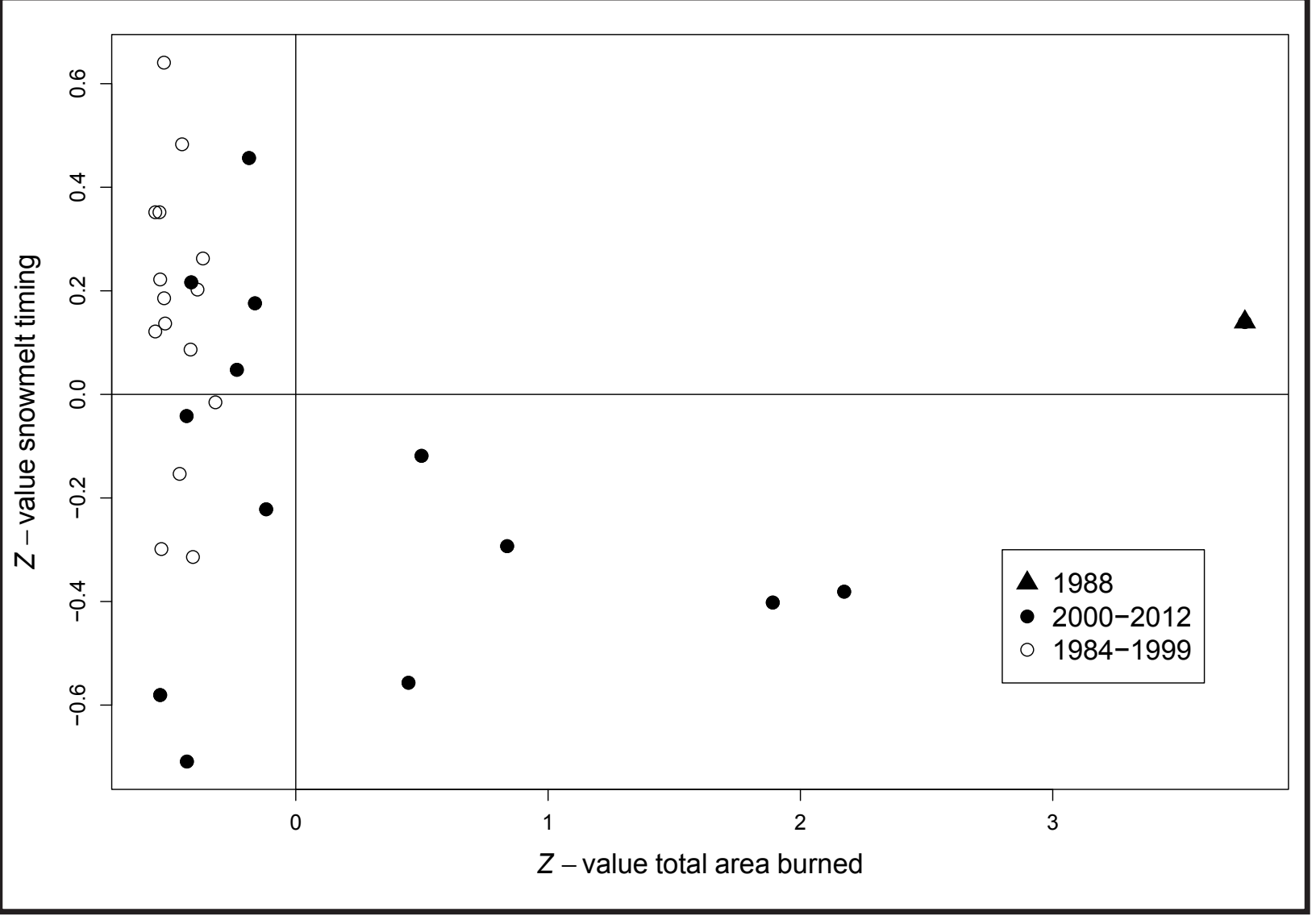

Figure 3. Scatterplot of snowmelt date anomaly ( $Z$-value snow coverage) and total area burned anomaly (Z-value total area burned) from 1984 to 2012. The black triangle symbolizes 1988, and years 2001 to 2012 (corresponding to MODIS period of record) are symbolized as black circles. All other years are open circles. Year 1988 is the only point in the positive-positive quadrant - the only year on record with above-average area burned following a later than average snowmelt. Years 2000 to 2012 contain all of the other above-average fire years for this period.

Our findings suggest that snowmelt occurring earlier in the coming decades will exacerbate wildfire risk. If this relationship continues to persist, we can expect an increase of wildfire annual area burned in the twenty-first century.

The link between snowmelt and annual area burned is apparent for the large increase in fire activity from 2000 to 2012, which coincides with a decade of early snowmelt (Figure 2). Indeed, aside from 1988, all above-average fire years occur within the 2000 to 2012 subset (Figure 3). Examination of the scatterplot (Figure 3) reveals a clear pattern that the majority of above-average fire years follow an early snowmelt anomaly, similar to findings in Medler et al. (2002). We can see in the full period of record that there is only one point (1988) that experiences a higher than average fire season following a positive snowmelt anomaly (later than average snowmelt date). All other above-average fire years follow a negative snowmelt anomaly (earlier than normal melt). There are many years with a low total annual area burned, regardless of the snowmelt anomaly. However, the years with high fire totals almost exclusively follow early snowmelt anomalies. This indicates that late snowmelt anomaly has a suppressive effect on wildfires, whereas early snowmelt anomalies are one factor in many that contribute to large fire years. 
Early snowmelt is one way to achieve low fuel moisture and extended fire seasons leading to increased annual area burned, yet it is certainly not the only mechanism. Climate indirectly affects wildfire occurrence, through control over fuel moisture (Gedalof et al. 2005, Miller et al. 2008, Littell et al. 2009, Fauria et al. 2011, Higuera et al. 2015). Dry fuel loads with adequate ignitions lead to wildfires. Fuel moisture is influenced by a variety of ecological and climatic processes including high summer temperatures, drought, and snowmelt timing. Of all the factors that lead to low fuel moisture, snowmelt timing is one of the earliest predictors, occurring several months before the fire season begins. Drought indexes, fuel moisture metrics, and spring-summer temperatures may be more highly correlated with annual area burned (Gedalof et al. 2005, Westerling et al. 2006, Miller et al. 2008, Spracklen et al. 2009, Higuera et al. 2015), but are temporally concurrent with wildfire season. Our model of classifying early snowmelt timing using Rutgers Global Snow Lab analysis of NOAA daily snow maps may provide months of foresight for wildland fire managers.

While climate variables such as PDSI and air temperature have a high explanatory power for wildfire $(\sim 50 \%)$, snowmelt timing explains very little of the variability in annual area burned $(\sim 14 \%)$. This is not a surprise, because snowmelt occurs months before the typical fire season, and there are many factors that can influence fire conditions in the interim. Nonetheless, fire managers should include snowmelt timing in any predictive analysis as snowmelt can directly influence fuel moisture levels, which serve as one factor in many that lead to large wildfire years.

We decided a priori that the year 1988 was an outlier as it clearly had the largest annual area burned and a slightly later than average snowmelt (Figure 2, Figure 3). The majority of the fires that make up the total acreage in our study area in 1988 occurred in the Greater Yellowstone Ecosystem, burning over 250000 ha in the surrounding areas. The large 1988 fires can be explained by many factors aside from snowmelt timing. The primary consensus of why this fire complex became so large was the combination of unusual weather conditions characterized by prolonged summer drought and extreme wind coupled with the vast extent of continuous lodgepole pine ( $P i$ nus contorta Douglas ex Loudon) forest (Romme and Despain 1989, Turner et al. 1994, Higuera et al. 2010). Historical evidence suggests that similar large fire events have occurred in Yellowstone on the order of 150- to 300-year intervals, occurring circa 1240, 1540, and 1700 (Higuera et al. 2010). The extensive fires in 1988 were caused by interactions of climate and fuel conditions, and correspond to a natural historical MFRI of $150 \mathrm{yr}$ to $300 \mathrm{yr}$ (Romme and Despain 1989, Turner et al. 1994, Higuera et al. 2010).

Early snowmelt is correlated with above-average wildfire occurrence, but it is not the only factor. When looking at the complete data set, the Spearman's rank correlation results suggest that late snowmelt's suppression of the following fire season's annual area burned is unlikely to be random. Omitting the year 1988 shows an even stronger inverse relationship for all but the most extreme fire year. Removing 1988 is justified because this well-studied complex was caused by extreme weather following snowmelt, and by omitting this data point we are better able to see the influence of periodic fires rather than widespread stand-replacing fires. Regardless of the cause of the 1988 fires, the fire regimes of this region are shifting due to earlier snowmelt and longer fire seasons, which is predicted to dramatically alter the ecosystem by the mid-twenty-first century (Westerling et al. 2011).

\section{Further Investigations}

Future research may seek to improve upon this analysis by using an updated MTBS dataset or higher-resolution imagery. The National Snow and Ice Data Center's MOD10A2 data- 
set has recently become popular (Hall et al. 2006). However, with its period of record extending back only to 2000, analyzing these higher-resolution data at a regional scale over this short period may fail to identify the relationships at play. Indeed, analysis of the subset from 2000 to 2012 yields no statistically significant relationship between snowmelt anomaly and wildfire. Improvements upon the snowmelt timing logic may be helpful in investigating the influence of spring snow storms following a lengthy period of no snow.

\section{Conclusions}

We have presented a novel method of comparing snowmelt data and fire occurrence using fine-scale resolution NOAA snow and MTBS fire data. We have improved upon existing methods by combining remotely sensed data with an algorithm that temporally averages snowmelt timing, better identifying the DOY when snow leaves the landscape. The fire regimes of various ecosystems respond differently to climatic conditions (Littell et al. 2009). Our model allows for simple comparison of snowmelt timing and annual area burned in a region of interest, and could easily be adapted across the continent or anywhere else that has a high-quality fire dataset. Further investigation could use our model on more EPA ecoregions, or improve upon the resolution of the snow extent data. Our findings bolster the results of previous studies, and further elucidate early spring snowmelt as a correlate of increased annual area burned. As snow continues to melt earlier each decade as a result of climate change, understanding this system may become increasingly important for wildfire management. Our model provides a novel tool for making general predictions about the upcoming fire season months in advance, and warrants extensive further investigation.

\section{ACKNOWLEDGEMENTS}

We would like to thank two anonymous reviewers, particularly reviewer \#2, who provided extensive insightful and constructive feedback that greatly improved this manuscript. Finally, we wish to acknowledge Dr. T. Ingalsbee for his efforts in cultivating a supportive environment for student development and facilitating discussion on this research through the Association for Fire Ecology's sixth international fire ecology and management congress.

\section{LITERATURE CITED}

Baker W.L. 2009. Fire ecology in Rocky Mountain landscapes. Island Press, Washington, D.C., USA.

Dennison, P.E., S.C. Brewer, J.D. Arnold, and M.A. Moritz. 2014. Large wildfire trends in the western United States, 1984-2011. Geophysical Research Letters 41: 2928-2933. doi: 10.1002/2014GL059576

Fauria, M.M., S.T. Michaletz, and E.A. Johnson. 2011. Predicting climate change effects on wildfires requires linking processes across scales. Wiley Interdisciplinary Reviews-Climate Change 2: 99-112. doi: 10.1002/wcc.92

Finco, M., B. Quayle, Y. Zhang, J. Lecker, K.A. Megown, and C.K. Brewer. 2012. Monitoring Trends and Burn Severity (MTBS): monitoring wildfire activity for the past quarter century using LANDSAT data. Pages 222-228 in: R.S. Morin and G.C. Liknes, compilers. Moving from status to trends: Forest Inventory and Analysis (FIA) Symposium. USDA Forest Service General Technical Report NRS-P-105, Northern Research Station, Newtown Square, Pennsylvania, USA. 
Gedalof, Z., D.L. Peterson, and N.J. Mantua. 2005. Atmospheric, climatic, and ecological controls on extreme wildfire years in the northwestern United States. Ecological Applications 15: 154-174. doi: 10.1890/03-5116

Hall, D.K., V.V. Salomonson, and G.A. Riggs. 2006. MODIS/Terra snow cover 8-day L3 global 500m Grid. Version 5. NASA National Snow and Ice Data Center Distributed Active Archive Center, Boulder, Colorado, USA. <https://nsidc.org/data/mod10a2>. Accessed 22 December 2014.

Higuera, P.E., C. Whitlock, and J. Gage. 2010. Linking tree-ring and sediment-charcoal records to reconstruct fire occurrence and area burned in subalpine forests of Yellowstone National Park, USA. The Holocene 21: 327-341. doi: 10.1177/0959683610374882

Higuera, P.E., C.E. Briles, and C. Whitlock. 2014. Fire regime complacency and sensitivity to centennial through millennial scale climate change in Rocky Mountain subalpine forests, Colorado, USA. Journal of Ecology 102: 1429-1441. doi: 10.1111/1365-2745.12296

Higuera, P.E., J.T. Abatzoglou, J.S. Littell, and P. Morgan. 2015. The changing strength and nature of fire-climate relationships in the US Northern Rockies, 1902-2008. PLoS ONE 10(6): 1-21. doi: 10.1371/journal.pone.0127563

Littell, J.S., D. McKenzie, D.L. Peterson, and A.L. Westerling. 2009. Climate and wildfire area burned in western US ecoprovinces, 1916-2003. Ecological Applications 19: 1003-1021. doi: 10.1890/07-1183.1

Medler, M.J., P. Montesano, and D. Robinson. 2002. Examining the relationship between snowfall and wildfire patterns in the western United States. Physical Geography 23: 335-342. doi: 10.2747/0272-3646.23.4.335

Miller, J.D., H.D. Safford, M. Crimmins, and A.E. Thode. 2008. Quantitative evidence for increasing forest fire severity in the Sierra Nevada and southern Cascade Mountains, California and Nevada, USA. Ecosystems 12: 16-32. doi: 10.1007/s10021-008-9201-9

Moore, C., S. Kampf, B. Stone, and E. Richer. 2014. A GIS-based method for defining snow zones: application to the western United States. Geocarto International 30: 62-81. doi: 10.1080/10106049.2014.885089

MTBS Project. 2014. MTBS Data Access: National MTBS Burned Area Boundaries. USDA Forest Service and US Geological Survey. <http:/www.mtbs.gov/nationalregional/burnedarea. html>. Accessed 7 June 2015.

Narasimhan, R., and D. Stow. 2010. Daily MODIS products for analyzing early season vegetation dynamics across the North Slope of Alaska. Remote Sensing of Environment 114: 12511262. doi: 10.1016/j.rse.2010.01.017

Robinson, D.A., T.W. Estilow, and NOAA CDR Program. 2012. NOAA Climate Date Record (CDR) of Northern Hemisphere (NH) Snow Cover Extent (SCE), version 1. (Weekly Snow Cover Extent). Rutgers University Global Snow Lab. <http://climate.rutgers.edu/snowcover/ docs.php?target=datareq $>$. Accessed 18 November 2014.

Romme, W.H., and D.G. Despain. 1989. Historical perspective on the Yellowstone fires of 1988. Bioscience 39: 696-699. doi: 10.2307/1311000

Schumacher, S., and H. Bugmann. 2006. The relative importance of climatic effects, wildfires and management for future forest landscape dynamics in the Swiss Alps. Global Change Biology 12: 1435-1450. doi: 10.1111/j.1365-2486.2006.01188.x

Semmens, K.A., and J. Ramage. 2012. Investigating correlations between snowmelt and forest fires in a high latitude snowmelt dominated drainage basin. Hydrological Processes 26: 2608-2617. doi: 10.1002/hyp.9327 
Spracklen, D.V., L.J. Mickley, J.A. Logan, R.C. Hudman, R. Yevich, M.D. Flannigan, and A.L. Westerling. 2009. Impacts of climate change from 2000 to 2050 on wildfire activity and carbonaceous aerosol concentrations in the western United States. Journal of Geophysical Research 114(D20301): 1-17. doi: 10.1029/2008jd010966

Stewart, I.T. 2009. Changes in snowpack and snowmelt runoff for key mountain regions. Hydrological Processes 23: 78-94. doi: 10.1002/hyp.7128

Turner, M.G., W.W. Hargrove, R.H. Gardner, and W.H. Romme. 1994. Effects of fire on landscape heterogeneity in Yellowstone National Park, Wyoming. Journal of Vegetation Science 5: 731-742. doi: 10.2307/3235886

US EPA [US Environmental Protection Agency]. 2003. Level III Ecoregions of the continental United States. National Health and Environmental Effects Research Laboratory, Washington, D.C., USA. <http://pubs.usgs.gov/tm/04/c03/virtual-CD/useco.pdf >. Accessed 26 January 2015.

Westerling, A., H. Hidalgo, D. Cayan, and T. Swetnam. 2006. Warming and earlier spring increase western US forest wildfire activity. Science 313: 940-943. doi: 10.1126/science. 1128834

Westerling, A., M.G. Turner, E.A.H. Smithwick, W.H. Romme, and M.G. Ryane. 2011. Continued warming could transform greater Yellowstone fire regimes by mid-21st century. Proceedings of the National Academy of Sciences 108: 13165-13170. doi: 10.1073/pnas.1110199108

Westerling, A., T. Brown, T. Schoennagel, T. Swetnam, M. Turner, and T. Veblen. 2014. Climate and wildfire in western US forests. Pages 81-102 in: V.A. Sample and R.P. Bixler, editors. Forest Conservation and Management in the Anthropocene. USDA Forest Service Proceedings RMRS-P-71, Rocky Mountain Research Station, Fort Collins, Colorado, USA. 